研究

\title{
金属ガラスの構造に関する新しい概念の提案
}

\author{
松原英一郎 \\ 京都大学工学研究科, $\bar{\top}$ 606-8501 京都市左京区吉田本町.
}

\section{A Proposal for the New Concept of Structures of Metallic Glasses}

\begin{abstract}
Eiichiro Matsubara
Department of Materials Science \& Engineering, Kyoto University, Yoshida-honmachi, Sakyo-ku, Kyoto 606-8501, Japan.
\end{abstract}

Received July 23, 2009

\section{SYNOPSIS}

Structural analyses of conventional amorphous alloy $\mathrm{Zr}-\mathrm{Ni}$ and metallic glass $\mathrm{Zr}$ - $\mathrm{Al}$-Ni have been studied in combination of measurements by neutron diffraction and $\mathrm{x}$-ray diffraction, and their structural models have been built with the reverse-Monte Carlo method by Fukunage et al. The structural models provided us some important results. Firstly, the density of icosahedron-like polyhedra increases in the metallic glass in comparison with the conventional amorphous alloy. Secondly, the structures of amorphous alloys which include the conventional amorphous alloys as well as the metallic glasses would be characterized by the three distinct polyhedra, that is, the icosahedron-like polyhedra (I), the trigonal prism-like polyhedra (P) and the polyhedra (W) which do not belong to either. As mentioned above, the ' I ' polyhedra are commonly found in the metallic glasses. The ' $\mathrm{P}$ ' polyhedra resemble the local atomic configurations of the primary crystalline phase precipitated in the amorphous matrix. Thus, the glass formability has been determined by the competition between ' $I$ ' and ' $P$ '. The ' $W$ ' polyhedra appear in the metallic glass with increase in the fraction of ' $I$ '. They show large coordination numbers more than 13. Taking into consideration of the atomic sizes of the constituents, $W$ is a polyhedron consisting of weakly bonded atoms in comparison with I and P. A spatial distribution of W controls the inhomogeneity of the metallic glass and is profoundly related with the fragility and other physical properties.

\section{KEY WORDS}

metallic glass, amorphous alloy, Zr-based alloy, Pd-based alloy, structure

\section{1 緒言}

アモルファス金属を作製するには液体を超急冷する必要が ある.ところが1990年代初めに, 東北大金研井上らのグル一 プによって，ある特定の合金系で比較的ゆっくりした冷却速 度でもアモルファス化することが見出された．通常のアモル ファス金属を加熱すると結晶化するが, この新たに見出され たアモルファス金属を加熱するとガラス転移を示し, 数 $10 \mathrm{~K}$ 程度の温度幅の過冷却液体領域を示した後, 結晶化する. 井 上ら ${ }^{1)}$ は, この新しいアモルファス金属を通常のアモルファ ス金属と区別し「金属ガラス」と名付けた。平成 $15 \sim 19$ 年度 まで文部科学省科学研究費補助金特定領域研究「金属ガラス の材料科学」(http://glasmet.imr.tohoku.ac.jp)では，この金属力 ラスの構造安定化機構と変形メカニクスの解明について重点
的に研究が行われた，その結果，本来アモルファス金属の一 種である金属ガラスがなぜ従来型のアモルファス金属に比べ て安定であるか, また金属ガラスは極めて高い弾性強度を示 すが，延びは注とんど示さず破断し，これらの機械的特性が 金属ガラスの内部構造に極めて敏感であることなどが明らか になった.これらの知見に基づいて, 阪大渋谷, 大阪府大東 らとの議論を通して, 金属ガラスの構造に関する新たな考え 方に至った. 本稿では, この考え方について，その経緯と共 に紹介する。

\section{2 アモルファス金属安定性の起源}

金属ガラスは, 従来型アモルファス金属と異なり, 可逆的 なガラス転移を示し, 数 $10 \mathrm{~K}$ 以上の大きい温度幅の過冷却液 
体領域が存在する. 金属元素を主成分としているにもかかわ らず，従来型アモルファス金属に比べて，金属ガラスがなぜ 優れた構造安定性を示すのか，その起源は，アモルファス金 属の結晶化温度とガラス転移温度の加熱速度依存性を系統的 に測定することで理解できる. Fig.1に示したのは, $\mathrm{Zr}_{70} \mathrm{Ni}_{30}$ と $\mathrm{Zr}_{70} \mathrm{Cu}_{30}$ 二元系アモルファス金属のガラス転移温度と結晶化 温度の加熱速度依存性である. ガラス転移温度および結晶化 温度が，加熱速度の対数に対して直線関係を示すのは, Chen ら2)が指摘した金属ガラスのガラス転移と結晶化過程が，ガ ラス固体あるいは過冷却液体の粘性流動の熱活性化過程であ ることによって説明できる。これら直線の傾きは，それぞれ の現象の活性化エネルギーの逆数に比例する.それぞれの合 金の結晶化温度およびガラス転移温度を,それぞれの液相温 度で規格化し，両方のアモルファス金属の挙動を比較すると

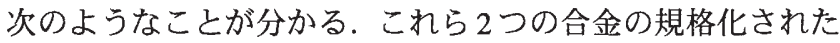
ガラス転移温度はほぼ同じ温度域にあるにもかかわらず, $\mathrm{Zr}_{70} \mathrm{Cu}_{30}$ の規格化された結晶化温度は $\mathrm{Zr}_{70} \mathrm{Ni}_{30}$ のそれに比べ, 高温側に大きくシフトしている3 ${ }^{3}$ ，すなわち，アモルファス 金属の安定性は, 結晶化を如何に抑制するかで変わってくる ことが明膫に示されている. 液相やアモルファス相からの結 晶化をできるだけ抑制することによって，比較的ゆっくりし た冷却速度や加熱速度でも明膫なガラス転移が観察され，大 きな過冷却液体領域を示す金属ガラスと呼ばれるアモルファ ス金属が出現する. 金属ガラスにおりて結晶化を抑制するア モルファス金属の構造はどのようなものであるか, 詳細につ いてはまだ多くの議論を必要とするが, 局所構造については, ほぼ明らかになっている。

福永ら ${ }^{4}$ は中性子回折とX線回折によるデー夕を組み合わ せ, リバースモンテカルロ(RMC)法を用いてアモルファス金 属 $\mathrm{Zr}_{70} \mathrm{Ni}_{30}$ と金属ガラス $\mathrm{Zr}_{70} \mathrm{Ni}_{20} \mathrm{Al}_{10}$ の構造モデルを実験的に 決定した.これらの構造モデルにボロノイ多面体解析を適用 し, 最近接原子周りの配位数が 11 から 12 の 20 面体的クラス ターの密度が, Fig.2に示すように, アモルファス相の構造安

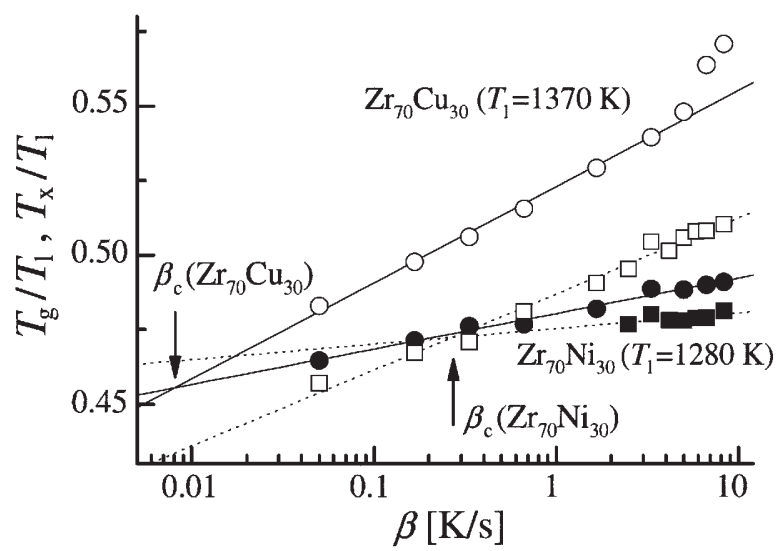

Fig.1 Heating-rate dependence of reduced glass transition and crystallization temperatures for $\mathrm{Zr}_{70} \mathrm{Cu}_{30}$ and $\mathrm{Zr}_{70} \mathrm{Ni}_{30}$ amorphous alloys.
定性が良好な金属ガラス $\mathrm{Zr}_{70} \mathrm{Ni}_{20} \mathrm{Al}_{10}$ では, 従来型アモルファ スである $\mathrm{Zr}_{70} \mathrm{Ni}_{30}$ に比べて, 飛躍的に増大することを示した。 アモルファス金属 $\mathrm{Zr}_{70} \mathrm{Ni}_{30}$ の構造解析を行うと, $\mathrm{Zr}-\mathrm{Ni}$ 原子ペ アの原子間距離が原子半径から予想される原子間距離に比べ て $5 \%$ ほど短くなっており, $\mathrm{Zr}$ と Ni原子間に強い化学結合が 存在することが分かる5).この強いZr-Ni結合の存在は, アモ ルファスの構造だけでなく,アモルファスが結晶化する際の 初期結晶相 $\mathrm{Zr} 2 \mathrm{Ni}$ の構造にも影響を与え，アモルファス相と 初期結晶相の最近接原子配列は，お互いに似た構造を示す。 そのため $\mathrm{Zr}_{70} \mathrm{Ni}_{30}$ の場合は, 超急冷をして結晶化を抑制するこ とによって初めてアモルファス化する.これに対して, $\mathrm{Al}$ の 添加によってこのような傾向が部分的に解消され, 20 面体的 クラスター密度が上昇し, 原子が密に詰まった局所構造が生 まれ結晶化が抑制されて, ガラス構造が安定化される. 次に 問題となるのは, これら 20 面体的クラスターが集合してでき る構造がどのようなものであり, どの程度の大きさを持つの かということである。結論からいうとまだ明らかではない。 しかし, その不均一構造の大きさのオーダーは, 内部摩擦を 利用した構造緩和実験やX線非弾性散乱測定などから明らか になってきている.

\section{3 金属ガラスの不均一構造}

金属ガラス $\mathrm{Pd}_{42.5} \mathrm{Ni}_{7.5} \mathrm{Cu}_{30} \mathrm{P}_{20}$ の場合，ガラス転移近傍で, サブMHz程度の超音波振動を与えて内部摩擦を測定すると, $\beta$ 緩和之呼ばれる構造緩和が観察される ${ }^{6}$.この $\beta$ 緩和は, Pd 基金属ガラス中の非金属 $\mathrm{P}$ と金属元素との間の共有結合的な 強い化学結合に対して, 金属元素同士の相対的に弱い結合で の構造緩和であると考えられる。実際，ガラス転移温度近傍 の $\beta$ 緩和を起こす領域で, サブ MHz程度の超音波振動を試料 に与えて, 緩和による原子の移動を促進し，その結果アモル ファス相が部分的に結晶化することを用いて，金属ガラス中 で $\beta$ 緩和を起こしている部分を観察することができる.この 部分結晶化した組織は, アモルファス母相中に結晶相が析出 するアモルファス相を部分結晶化させた組織と異なり,アモ ルファス相を取り囲むように結晶相が存在する.したがって，

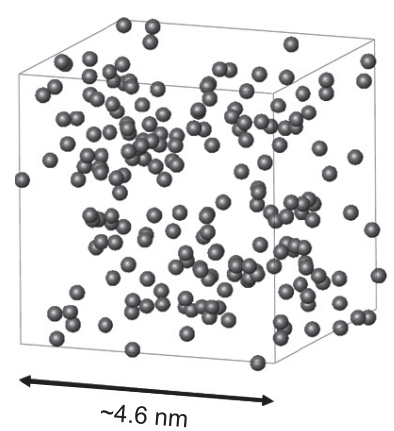

(a)

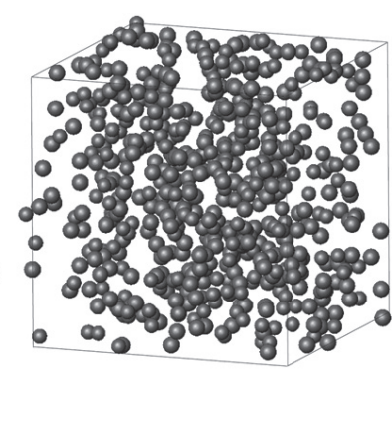

(b)
Fig.2 Distribution of center atoms of icosahedron-like clusters in the structural models constructed from the reverse MonteCarlo simulation using $\mathrm{x}$-ray and neutron diffraction data. 
この結晶相が取り囲むアモルファス相の大きさから，金属ガ ラス $\mathrm{Pd}_{42.5} \mathrm{Ni}_{7.5} \mathrm{Cu}_{30} \mathrm{P}_{20}$ では構造不均一の大きさは約数 $\mathrm{nm}$ 程度 であることが分かる. 金属ガラス中にこのような構造不均一 が存在すると, 金属ガラス中を伝播するフォノンの波長が, 構造不均一の大きさに比べて十分大きい場合には影響を受け ないが, フォノンの波長が構造不均一の大きさと同程度の大 きさになると，構造不均一による減衰の影響を受ける。この ことを利用し， X 線非弾性散乱を用いて，非弾性散乱のピ一 ク位置とピーク幅からそれぞれフォノンの伝播速度とフォノ ンの隇衰時間を実験的に見積もり, 金属ガラス中のフォノン の伝播距離を計算することができる7). Fig.3に示したのは, Pd 基および $\mathrm{Zr}$ 基金属ガラスについて実験的に求めたフォノン の伝播距離を波数の関数でプロットした図である.これらの 図から分かるように, フォノンの伝播距離がある特定の波数 で急激に増加する. 伝播距離が大きく変化する波数の臨界值 は，上で述べたように金属ガラス中を伝播するフォノンの波 長が, 金属ガラスの不均一構造のサイズとほぼ同じくなる波 長に対応すると考えられる.すなわち，臨界值を与える波数 から不均一構造の平均サイズを見積もることができる.この ことを使って Pd基および $\mathrm{Zr}$ 基金属ガラスにおいて，不均一 構造の平均サイズは, それぞれ約 $4.3 \mathrm{~nm}, 2.1 \mathrm{~nm}$ となる. Pd基 金属ガラス中の特徵的なクラスター構造はP原子を中心にし たアルキメデス型のプリズム構造であり, $\mathrm{Zr}$ 基金属ガラスで はCu原子周りに形成された 20 面体的クラスター構造である ことが知られている.したがって, Pd基金属ガラスの局所構 造の方がZr基金属ガラスのそれに比べて若干大きいことが予 想される.すすおわ ここれら局所構造が集まってできている と考えられる構造不均一のサイズにも, 局所構造の大きさが ある程度反映されている可能性がある.このような構造不均 一を考慮して，もう一度福永ら ${ }^{4)}$ が解析した構造モデルを見 ると, 重要なことに気づく.

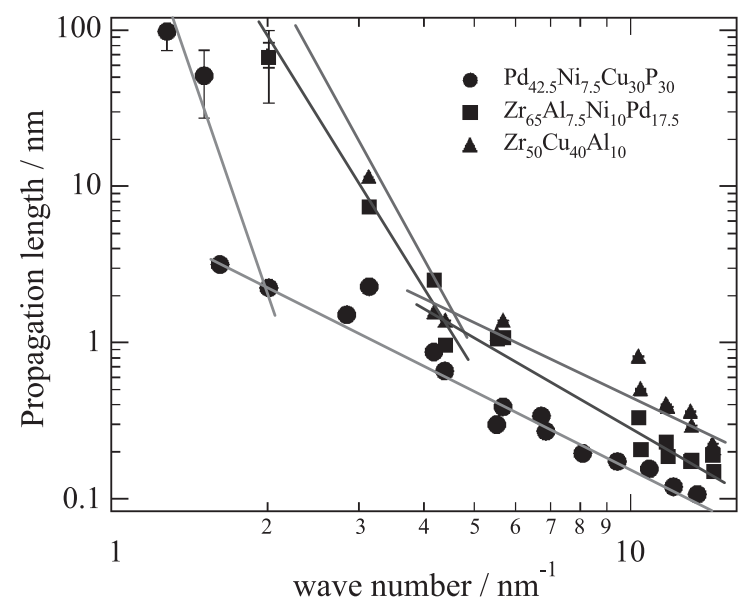

Fig.3 Propagation distances of phonons in some metallic glasses, which are calculated from the sound velocities and decay times in the inelastic $\mathrm{X}$-ray scattering measurements as a function of wavenumbers.

\section{4 構造不均一を考慮した金属ガラスの構造モデル}

Fig.4 (福永ら ${ }^{8)}$ による中性子線回折とX線回折データにリ バースモンテカルロ(RMC)法を適用し求めたアモルファス金 属 $\mathrm{Zr}_{67} \mathrm{Ni}_{33}$ と金属ガラス $\mathrm{Zr}_{65} \mathrm{Cu}_{27} \mathrm{Al}_{8}$ の実験構造モデルのボロ ノイ多面体解析結果である.これら多面体解析の結果を, $3 \supset$ の種類に大別する. まず一つめは, 先にも述べた金属ガラス 構造を特徵付ける20面体的多面体である.この多面体は配位 数が 11 から 12 であり, 原子が最密充填した構造を示す. 次 に, 従来型アモルファス中で多く見られるアモルファス相か ら析出する結晶相の局所構造に似た多面体構造である.この 多面体に分類されるのは, 三角プリズムを基本構造とする配 位数が 10 以下の多面体である. この 20 面体的多面体をI, 三 角プリズム多面体を $\mathrm{P}$ と説明のために名付けると, 三番目は, これらIにも $\mathrm{P} に も$ 属さないそれ以外の多面体である.この 三番目の多面体を W と名付けるとすると，このW は配位数 が13以上の比較的大きい配位数を示す多面体となる.このよ うな分類に基づいて, Fig.4の黒棒グラフで示した結果を見る と,アモルファス金属 $\mathrm{Zr}_{67} \mathrm{Ni}_{33}$ では, 20 面体的多面体Iよりも 三角プリズム的多面体Pが多く存在するのが分かる.すなわ ち，アモルファス金属を作製する場合，Pが再配列し結晶核 を形成するのを阻止するために液体を超急冷する必要がある. 一方, 金属ガラス $\mathrm{Zr}_{65} \mathrm{Cu}_{27} \mathrm{Al}_{8}$ では, Fig.4の灰色棒グラフに示 すように, Pの割合は相対的に大幅に滅少し，Iの割合が著し く増加する. すなわち P とIとの競合においてIの割合が増加 する.これにより結晶化が抑制されアモルファス相が安定化

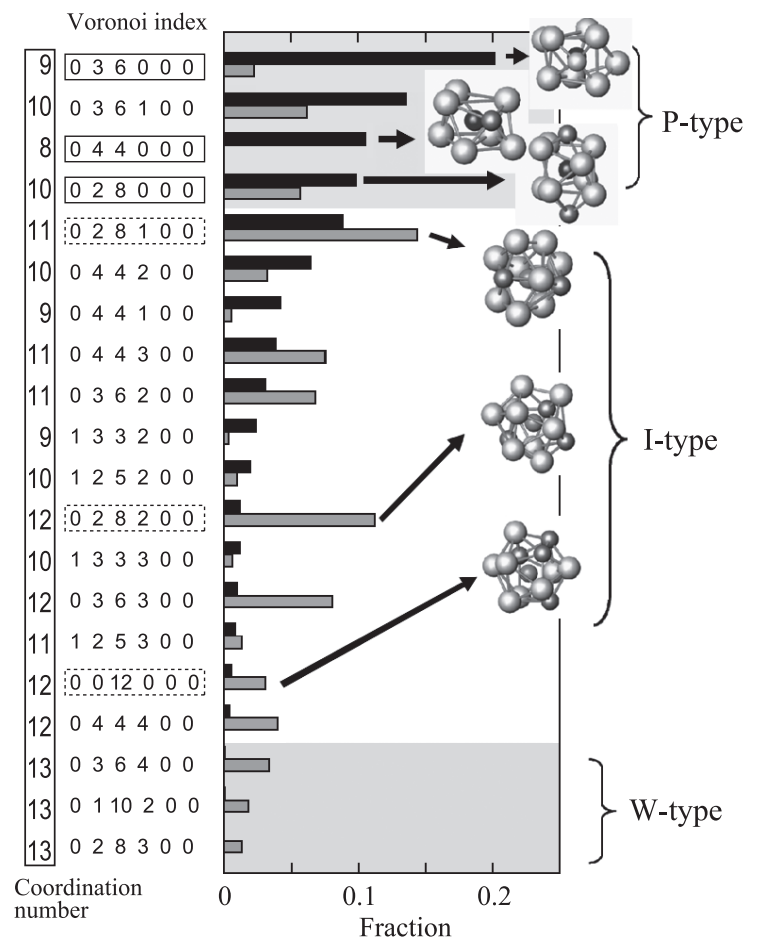

Fig.4 Voronoi analyses of the structures of conventional $\mathrm{Zr}_{67} \mathrm{Ni}_{33}$ amorphous alloy (grey bar chart) and $\mathrm{Zr}_{65} \mathrm{Cu}_{27} \mathrm{Al}_{8}$ metallic glass (black bar chart). 
される.これは上で述べた議論である。このようなこれまで 提唱されてきた構造的な違いに加え,Iの割合が增加した金属 ガラス中には, アモルファス金属ではほとんど存在しなかっ た，Iよりさらに大きな配位数の多面体Wが出現する。これ は20面体的多面体では, 三次元空間を完全に埋めることがで きないために多面体Wが必要になるとして理解することがで きる. Fig.4に示したように金属ガラス $\mathrm{Zr}_{65} \mathrm{Cu}_{27} \mathrm{Al}_{8}$ において, $\mathrm{Zr}$ より小さい原子半径の原子 $(\mathrm{Cu}, \mathrm{Ni}, \mathrm{Al})$ の周りで, 極めて大 きな配位数を示す多面体 W が存在することは，多面体 PやI に比べ隣接原子との原子間距離が長く, 結合が弱い領域が形 成されていると考えられる.このような領域は, Pd基金属ガ ラスにおいて $\beta$ 緩和を起こした領域に対応すると考えられ る.アモルファス金属や金属ガラスなど金属非晶質固体の構 造を, 特徵的な 3 種類の基本構造 $\mathrm{P}$ (アモルファス相から晶出 する結晶相の構造に似た原子配列を示す多面体)，I ( 金属の ガラス相を安定化させる充填原子配列を示す 20 面体的多面 体)，W (I, P以外の原子配列を示す多面体)に分割し，系統的 に調べ整理する「基本構造 $(\mathrm{P}, \mathrm{I}, \mathrm{W})$ の概念はは，従来型アモル ファス金属や金属ガラスの構造安定性を包括的に理解する上 で有効であると考えられる。

\section{5 ま と め}

アモルファス金属の構造安定性は, 結晶化を効果的に抑制 することによって改善される.したがって，大きさの異なる 原子をできるだけ密に詰め, それに付加的な要素として,より 複雑な結晶化過程を実現する合金系を選択することによって 金属ガラスが形成されることを提案した「井上の三原則」が示 していることと矛盾しない. 本稿で紹介した $\mathrm{Zr}-\mathrm{Ni}$ のように, 構成元素のある特定元素間の結合に極めて強い結合が存在す る場合やPなどの非金属元素を含む系の場合，強い結合は初 期結晶相にも反映され，結晶化を容易にし，ガラス構造安定 化の障害になる。しかし $\mathrm{Zr}-\mathrm{Ni}$ に $\mathrm{Al}$ や $\mathrm{Pd}-\mathrm{Ni}-\mathrm{P}$ に Cu な゙の 元素を添加して，ある特定の元素間の強い化学結合を部分的 に置換し，緩和することによって，アモルファス構造の安定 性は改善される。

金属ガラス中には, 大きく分けてP(アモルファス相から晶 出する結晶相の構造に似た原子配列を示す多面体)，I (金属 のガラス相を安定化させる充填原子配列を示す20面体的多面 体), W (I, P以外の原子配列を示す多面体)の 3 種類の役割の 異なる多面体が存在することが実験的に示される。これら 3 種類の多面体の割合が変化することで安定性や, 粘性, フラ ジリティーなどの物性が変化すると考えられる.さらに,こ
れらの多面体が組み合わされてできている金属ガラス構造中 には構造不均一が存在しており，合金系によってその不均一 構造の大きさは異なっていることが実験的に示される. Zr 基 金属ガラスでは約 $2 \mathrm{~nm}$ であり, Pd 基金属ガラスでは約 $4 \mathrm{~nm}$ 程度である.これらのサイズがごのようにして決まるのかは 明らかではない。 また，これらの構造不均一のサイズが，フ ラジリティーなどの金属ガラスの物性とどのように関係する かは, 今後の課題である.

なお, 本稿で紹介した研究結果は, 文部科学省科学研究費 補助金特定領域研究「金属ガラスの材料科学」および基盤研究 $\mathrm{A}\lceil\mathrm{X}$ 線回折·非弾性散乱之粘弾性周波数解析による金属ガラ ス不均一構造の発達過程」で得られた研究成果である.

\section{文献}

1) A. Inoue: "Stabilization of Metallic Supercooled Liquid and Bulk Amorphous Alloys", Acta mater., 48(1) (2000)279-306.

2) H.S. Chen: "Method for Evaluating Viscosities of Metallic Glasses from the Rates of Thermal Transformation", J. NonCryst. Solids, 27(1978)257-263.

3) E. Matsubara, T. Ichitsubo, J. Saida, S. Kohara, and H. Ohsumi: "Local Structure and Glass-Forming Ability in $\mathrm{Zr}$-Based Amorphous Alloys", J. Alloys Comp., 434-435(2007)119-120.

4) A. Hirata, T. Morino, Y. Hirotsu, K. Itoh, and T. Fukunaga: "Local Atomic Structure Analysis of Zr-Ni and Zr-Cu Metallic Glasses using Electron Diffraction", Materials Transactions, 48 (2007) 1299-1303

5) T. Ichitsubo, E. Matsubara, J. Saida, and H.S. Chen: "Local Structure and Glass Transition in Zr-Based Binary Amorphous Alloys", Mater. Trans., 46(2005) 2282-2286.

6) T. Ichitsubo, E. Matsubara, T. Yamamoto, H.S. Chen, N. Nishiyama, J. Saida, and K. Anazawa: "Microstructure of fragile metallic glasses inferred from ultrasound-accelerated crystallization in Pd-based metallic glasses", Phys. Rev. Lett., 95(2005)245501.

7) T. Ichitsubo, E. Matsubara, K. Miyagi, W. Itaka, K. Tanaka, and S. Hosokawa: "Low-temperature elastic moduli of a Pdbased metallic glass showing positive phonon dispersion", Physical Review B, 78(5) (2008)052202.

8) T. Fukunaga, K. Itoh, T. Otomo, K. Mori, M. Sugiyama, H. Kato, M. Hasegawa, A. Hirata, Y. Hirotsu, A.C. Hannon: "Voronoi Analysis of the Structure of Ni-Zr-Al Ternary Metallic Glass", Mater. Trans., 48(2007)1698-1702. 